\title{
Why include the BOP in your international marketing
} strategy

\begin{tabular}{|r|l|}
\hline Journal: & International Marketing Review \\
\hline Manuscript ID & IMR-03-2019-0097.R1 \\
\hline Manuscript Type: & Original Article \\
\hline Keywords: & $\begin{array}{l}\text { base of the pyramid, Marketing strategy, stochastic modelling, Consumer } \\
\text { Behaviour }\end{array}$ \\
\hline
\end{tabular}

SCHOLARONE ${ }^{m}$

Manuscripts 


\title{
Why include the BOP in your international marketing strategy
}

\begin{abstract}
Purpose -- This paper tests the premise that brand growth can come from targeting the poorest consumers at the bottom of the economic pyramid (BOP). This study is the first that uses quantitative marketplace data covering BOP consumer purchase records.

Design/Methodology/Approach -- The study uses newly available panel data from Egypt covering 15 months and 35 categories of frequently bought consumer goods. Brand penetration rates for socio-demographic tiers are established to explore brand purchasing. The metrics are: penetration, the number of buyers a brand has; and loyalty as measured by purchase frequency and share of category requirements.
\end{abstract}

Findings -- Buyer behavior patterns for the poorest consumers do not differ much from those in advanced economies; all brand performance metrics (BPMs) vary according to brand penetration-- a Double Jeopardy (DJ) effect, and the biggest brands are those that target the whole market, including the base.

Practical implications -- The biggest brands are those with the most customers, even if those customers are poor and do not buy very often. Growth can therefore be based on marketing interventions that appeal to the largest possible customer base.

Originality/value -- This paper extends previous research on brand buying behaviour for the first time to the vast base of poor consumers who make up around half of the world's population. This research shows that strategic approaches that emphasize increasing penetration are most likely to result in brand growth.

Keywords -- Base of the pyramid, brand strategy, Emerging markets, stochastic modelling

Paper type -- Research paper 


\section{Why include the BOP in your international marketing strategy}

"The Ehegwo family lives in Oguta in Nigeria. Jude is 40 years old and is a farmer. His wife Njideka is 25 years old and she is also a farmer. They are parents to 7 children and live with them in a rented 2-bedroom house. Their favorite item in the house is their clothes. The next thing they plan on buying is a mattress and their dream is to buy a house made of block walls.

In this household each adult can consume goods and services worth about 59 US dollars each month. This consumption includes the things they buy as well as the things they produce for themselves (if any). We estimated this amount based on the assets the family owned and the incomes they reported." source: Gapminder: Dollar Street, 2019

The Ehegwo's are a typical example of a bottom of the pyramid (BOP) household (see Figure 1). They were visited along with 253 other families at various income levels around the world as part of a project that aims to show "how people really live" through a standardized set of photos of living and sleeping areas, cooking facilities (figure 2), bathrooms, and household goods (Gapminder.org, 2019; Dollar Street). Only a small portion of featured households are amongst the very poorest, but they can be seen as representative of over two billion people who live on less than $\$ 2.50$ per day (most recent UN report, 2014) mostly in developing or emerging economies.

Figure 1 about here

The photos show that while these BOP households possess very little, they do have some of the things that the more affluent have in abundance--typically consumables such as 
toothpaste, detergent, and packaged food, but also mobile phones and sometimes TVs (figure 3). It is also noticeable that with even small increments in income between households, the number of branded items increases markedly.

Figure 2 about here

Surviving on $\$ 2.50$ a day is difficult or impossible for most people to imagine. So is being part of the informal economy where income is irregular and rarely means cash at the end of the day. At this level, most income is spent on basics, especially food (World Resources Institute, 2018), leaving families in suspense about funds for emergencies, or big-ticket items like a refrigerator or education for the children. So how do the very poorest people get the money to buy the things that appear in their homes?

Figure 3 about here

Part of the answer is that even the poorest do not consume all their income as soon as it is earned, but instead save when they can and borrow when they need to. With so little income, "money management is, for the poor, a fundamental and well-understood part of every day life," (Collins et al, 2011). This is not to cast value judgements on what poor people buy, or what they aspire to buy, it is merely evidence that they do. When circumstances allow, they increase both the quantity and quality of what they consume.

The future market potential of these consumers really caught the imagination of international firms when C.K. Prahalad published The Fortune at the Bottom of the Pyramid in 2005. Prahalad used case examples to make a compelling, if perhaps idealised 
argument for seeing, developing and enrolling the world's poorest people as participants in the modern economy, saying that while this is profoundly challenging, the effort could be amply repaid in the future.

This idea was rapidly challenged by many authors under titles such as Misfortune at the bottom of the pyramid (Karnani, 2007), and Reality Check at the Bottom of the Pyramid (Simanis, 2012), focusing on the difficulties inherent in tackling the BOP, criticising Prahalad's case studies and offering counter examples of frustrated companies that failed to find a fortune there, emphasizing the difficulties of operating in the poorest, least-developed markets, concluding that they are different enough to require a fundamental rethinking of established marketing assumptions (Sheth, 2011).

\subsection{The case for empirical evidence of BOP buying behaviour}

Kolk et al's (2014) systematic review of the BOP literature included 104 articles from 2000-2009, concluding that while the BOP concept had evolved over time, there is still little consensus on its definition. They called for more and different types of studies beyond the conceptual or case-study analyses (only four articles in their review used quantitative data, none dealing with consumer goods (CPGs)) and to broaden the setting beyond the Asian/SE Asian context where the majority of studies was conducted.

The theoretical contribution to the BOP debate made by the current research comes not from individual case studies, but from applying a highly generalised stochastic model to evaluate newly available panel data records of BOP buyer behaviour. The study examines brand choice behavior in 35 CPG categories over fifteen months. In doing so, it begins to fill the gap between theory and practice, focussing on the empirical evidence. The approach takes as its starting point the idea that at their core all markets are composed of suppliers, customers and the purchases they make, therefore the aggregate 
outcomes of what is bought, who is buying and how often they buy, even in an unfamiliar BOP market context can be better understood by benchmarking against the law-like patterns of consumer brand choice found in other markets. The research demonstrates that existing models and knowledge can be extended, and that no new model of marketing may be required in markets with large numbers of BOP households.

The findings reveal that the main patterns of brand choice behavior in the BOP segment do not vary greatly from higher income segments, nor are they very different to those found in advanced economies. Competitive market structures reflect and can be explained by the behavioural norms established by Ehrenberg (1988) and extended by Sharp et al (2017). In the BOP as elsewhere, the common behavioural brand loyalty metrics (average purchase frequency, share of category requirements, buying heterogeneity) are closely correlated with each other, vary according to, and are predictable from brand size, and reflect a Double Jeopardy (DJ) characteristic (Ehrenberg et al., 2004). The theoretical assumptions underpinning the Double Jeopardy Law therefore reveal important similarities in buying behaviour between and across market segments where buyers hold different brand repertoires and buy at different rates.

Second, the evidence shows that in each category, BOP buyers invariably already use the leading brands, which are indigenous brands in some categories, but regional or global in others. What separates the smallest from the largest brand in every case is not country of origin or rate at which they are chosen (loyalty levels between competing brands vary little), but the number of people who buy them at all. The third finding is therefore that the big fight is not at the top, nor even as Brandt \& Thun (2010) argued, in the middle, but rather for the whole market. In many markets, that means targeting the BOP. 
Finally, the leading brand in the BOP context is often very much larger than its closest competitor - on average, twice its size. The gap suggests that valuable market leadership can be achieved (and perhaps maintained) by leveraging competitive advantages of scope and scale from broad market coverage that includes masses of consumers even though most of them are light buyers - in other words, targeting the BOP repays the effort.

These findings are important for the development of empirically grounded theory and reinforce established empirical generalizations. Further, they provide brand management with a simple measure to understand market structure, evaluate past performance and develop realistic strategies in pursuit of market penetration.

This paper proceeds as follows: section 2 elaborates the empirical generalisations that are extended to a BOP context, their theoretical underpinnings and the model adopted to describe them. The salient features of a BOP market are then presented, followed by the dataset, with validation, and a brief description of the analysis. The main findings follow, capped with a conclusion and discussion of the contributions made by the research.

\section{Buying behaviour in the BOP}

Member countries of The World Trade Organization (WTO) classify themselves as either "developed" or "developing," but without exactly defining either term. Two-thirds of the WTO's 164 members are developing countries (WTO, 2018) while 47 are least developed countries (LDCs). Both tend to have large BOP segments and are economically, demographically, culturally and socio-politically different from developed markets and from each other (Luiz, 2006, Sheth 2011), but the important point is that they often have rapidly growing populations, expanding middle classes, and a rising demand for brands 
and innovations (Cateora et al, 2014; Coussy, 2009; Bang et al, 2016). Such economies present major international marketing opportunities because sales growth and global share gain may come faster than in stable slow-growing zero-sum markets in developed countries (Hanssens \& Pauwels, 2016; Trinh and Anesbury, 2015). In addition, many BOP markets are very large (see Table 1) and while per capita income is very low, the huge numbers aggregate to high purchasing power (Prahalad, 2005; Nakata \& Weidner, 2012; Chikweche, 2013) of about \$5 trillion worldwide (World Resources Institute, 2018), concentrated on sectors such as food, energy and housing.

Table 1 about here

Many BOP articles advise managers to appreciate how such markets differ (Ghemawat \& Altman, 2016; Luiz, 2006), stressing underdeveloped infrastructure (Weissburg, 2008), inadequate and complex legal systems (Miller, 1998), limited income and low education levels (Jagtap et al, 2014) which in turn affect buying behaviour (Batra, 1999) that in poorer communities is shaped by resource shortages and psychological, social and literacy barriers (Viswanathan \& Sridharan, 2012). BOP consumers may eschew nondiscretionary or expensive brands and instead spend cautiously on basic products (D’Andrea et al, 2010; Kotler \& Kotler, 2012), and their repeat brand purchasing is likely to be further reduced by unstable competitive sets, high levels of unbranded competition and imbalances between supply and demand (Cateora et al, 2014; Brown, 1995; Ghemawat \& Altman, 2016). Weak buying power and low levels of product penetration are thought to lead to unstable choice behaviours (Luiz, 2006), so marketers are advised to focus instead on establishing brand presence and distribution systems (Sheth, 2011; Eyring et al, 2011) before building customer loyalty, e.g. via a top down strategy that offers easy entry through the small, wealthy segment at the top of the pyramid before 
diffusing to the more difficult middle or bottom of the market (Brandt \& Thun, 2010). Some argue that naive and time-poor BOP consumers behave very differently and have low loyalty because they are trying brands for the first time (Chikweche, 2013; Nakata \& Weidner 2012; Hillemann \& Verbeke, 2014; Rangan et al, 2011) necessitating cleverly adapted marketing approaches (Jagtap et al, 2014; Hahn, 2009; Eyring et al, 2011).

The idea that BOP consumers must make brand choice decisions differently from the top, and certainly at variance with more developed markets where higher loyalty can be earned, is understandable but based on little evidence. Until now, the BOP literature stressing behavioural differences and barriers to entry is largely anecdotal and conceptual (Kumar, Sarang \& Sharma, 2015) and when tested or measured is likely to use qualitative or case-study based data (Kolk et al, 2014).

A better empirically-based understanding of brand choice behaviour at the BOP could therefore inform knowledge of brand diffusion processes, particularly if there is evidence for differences in behavioural loyalty. To understand the extent to which the poorest really differ in their buying, behavioural benchmarks are needed. Fortunately there is a developed literature with generalised models of aggregate brand performance in the form of empirical generalisations, and one in particular describes behavioural loyalty, the Double Jeopardy Law (Ehrenberg et al., 1990). The next section reviews this literature and develops the research question.

\subsection{Empirical generalisations in marketing}

An empirical generalisation (EG) is a relationship between two or more variables that has been widely observed to hold across a range of conditions (Uncles and Wright, 2004). EG's are managerially useful because they predict: "what tends to happen to consumer 
behavior and, therefore, business performance, when a firm, brand or other relevant entity engages in a certain marketing behavior" (Hanssens, 2018 p.6).

Many EGs established in stationary markets reliably predict recurring patterns of buyer behaviour in terms of how many consumers buy, how often they buy and what else they buy (Bound, 2009). EG explanatory theory is integrated into the NBD-Dirichlet model of purchase incidence and brand choice (Goodhardt, Ehrenberg and Chatfield, 1984) but its components, including DJ may be applied independently to provide benchmarks in new marketing environments. Such differentiated replications would then reveal any contingency effects operating in the new contexts (Easton, 2002).

The idea that similar basic human needs shape the behavior of individuals regardless of where they live supports the supposition that many consumer-related constructs or EGs may indeed be universal. But if DJ is to be considered as a successful theory by Marketing Scientists, it must continue to predict in novel settings (Hunt, 1994). That is why Burgess and Steenkamp (2013) called for more testing in new market contexts, i.e. real-world learning laboratories, to develop contingency theory.

\subsection{Double Jeopardy}

DJ says that small brands are punished twice for being small: they have fewer buyers than bigger competitors, and those buyers are somewhat less loyal (Ehrenberg et al, 1990). The EG summarises the outcome effects of repeat buying in repertoire markets with a simple model that integrates the theoretical assumptions of the Law and predicts behavioural loyalty (purchase frequency) from brand size. 
Where $b$ is brand penetration - the number buying it at least once in a period - and $w$ is the average brand purchase frequency across those buyers, the model relates the values in the sales equations for competing brand $(x, y, \ldots . . n)$ described by the equation:

$$
w_{\mathrm{x}}\left(1-b_{x}\right)=w_{\mathrm{y}}\left(1-b_{\mathrm{y}}\right)=w_{o}
$$

The value $w_{o}$ is a constant for the category, estimated as the average value of $w(1-b)$ for all observed brands. The predicted value of $w_{\mathrm{x}}$ for a given $b_{\mathrm{x}}$ is therefore $w_{o} /(1-b)$, which shows that the fewer the buyers $(b)$ the smaller $w$ must be, the Double Jeopardy effect.

In this form the model makes two independence assumptions (Goodhardt et al, 1984). The first is that buying of different brands is independent across consumers (e.g. the proportion of households that buy brand $x$ in the period is $b_{x}$ irrespective of whether they also buy brand $y$ ); and second, brands do not differ in how often their customers buy the total category on average, and no one brand monopolises the heaviest category buyers.

It is still surprising to some that these assumptions are widely found to hold, but the EG has predicted loyalty in scores of product categories (Ehrenberg et al, 2004) over the past 50 years. It has been extended to product variants (Singh et al, 2004), TV programme choice (Ehrenberg et. al, 1990), retailing (Pleshko \& Souiden, 2007), fashion retail (Brewis-Levie \& Harris, 2000), sports teams (Doyle et al, 2013) and infrequently bought goods and brand extensions (Ehrenberg \& Goodhardt, 2001). The theory has made novel predictions about brand defection (Wright \& Riebe, 2010), mental market share (Romaniuk, 2013), social marketing (Gruneklee et. al, 2016) and anti-brand social media activity (Kucuk, 2010). 
The two assumptions suggest that buyers behave habitually because they are experienced with the category and the brands in their individual repertoires. A zero-order assumption also implies that category buying remains stationary. However, this may not be true for BOP segments where new buyers and new brand entrants may violate stationarity. Any deviation from theoretical values would show that the strict assumptions of the law have been breached (nevertheless providing valuable insight).

The Double Jeopardy law was developed in mature stable categories. Its No Segmentation assumption arises because households buy habitually from individually different repertoires of competing brands that they perceive as close substitutes. In aggregate this means first that the most popular brands get bought a little more frequently simply because rather more people know about them, and second most brand buyers in a given time period are light buyers of that brand and devote more of their category purchasing to other brands, so the number of buyers any brand attracts is the main determinant of performance.

\subsection{Extending the analysis to a new context}

The negative view of marketing barriers in BOP markets is likely based on an unrealistic view of brand loyalty. It supposes that at the BOP buyers are light for extrinsic reasons including spotty distribution, low disposable income, etc. but gives no evidence of loyalty at the BOP or any other level. However, it has been repeatedly shown that most brand buyers in any customer base are predictably light buyers (Graham et al, 2017). This should be the case at the BOP as well and means that brand strategy is obvious and tactics are clear - to deliver consistent penetration growth across the whole market (Dawes, 2016). 


\begin{abstract}
Almost all research involving stochastic modelling of consumer purchase data has been done in developed markets. Of the forty-six studies included in this EG review (appendix 1), $84 \%$ were conducted in highly developed markets, and the few that included data from developing markets (Thailand, South Africa, Indonesia, Nigeria, Kenya) did so at the category level without specifically looking at the BOP segment. To the best of the authors' knowledge, no previous analysis of BOP buying behaviour based on recorded purchase data has been published. It therefore remains an empirical question as to whether BOP consumers behave in ways that mirror more affluent consumers. The main research question is:
\end{abstract}

\title{
Does the Double Jeopardy Law apply at the bottom of the pyramid?
}

If BPMs are shown to be normal in the BOP, then DJ provides an excellent prescription for growth, since the greatest difference between competing brands is in the number of buyers each attracts. In context, the model predicts the necessary sales equation $(b \times w)$ for any planned market share, and this study examines brand buying through a DJ lens to understand the differences in BPM's between brands in the BOP.

The research contributes evidence-based knowledge of consumer behaviour, strengthens and extends useful empirical generalisations and provides managerial insight for strategic planning. The next section discusses the methodology employed, before presenting the results and their implications. 


\subsection{Method}

\subsection{Data}

This study analysed purchasing records in 35 CPG categories recorded by a consumer panel of 3265 households in Egypt. The panel was recruited for commercial purposes by Kantar-TNS to quotas that contained representatives from each socio-economic group (Figure 1) including BOP participants. Reporting quality was rigorously controlled. The income classifications are designed to be similar across countries or markets, dividing populations roughly by income quintiles. Markets with large BOP segments are highly skewed towards the poorest. For comparison, in the UK the C2, D and E segments account for around half the population; in Egypt, they account for $84 \%$, with $31 \%$ at the BOP, at incomes of $\$ 2.50$ USD per day or less.

Figure 4 about here

The panel data used here do not rely on respondents' unreliable memories or intentions (Sharp et. al, 2012; Malhotra et al, 2010) but are a comprehensive record of household purchasing. Nevertheless, this is a limited panel, so data for the smallest brands in the smaller categories risk some sample error. To minimize this, analysis for each category was conducted over the longest possible time period of fifteen months and restricted to the top 10 brands, generally accounting for over $90 \%$ of category sales.

\subsection{Analysis}

The CPG categories analysed included detergents, soaps and deodorants as well as food products including yoghurts, cereals, confectionery and processed cheese. Based on purchase occasion, category and brand performance measures were tabulated for the 
period to describe relative competitive outcomes; market share, penetration, average purchase frequency, behavioural brand loyalty metrics including relative proportions of heavy and light buyers, category purchases, share of category requirements and $100 \%$ loyal households.

Many international or global brands appear in the data but an obvious BOP market characteristic was a recurring "loose" brand classification within the top ten brands. These are generic products sold by weight or by the piece. This was treated in subsequent analysis as a discrete competitive entity.

The Double Jeopardy model was estimated for each category for the top ten brands and its fit evaluated, then BOP households were isolated from the panel and a further model fitting conducted to investigate the nature of BOP buying.

\subsection{Results}

This section presents an analysis of buying behaviour for laundry detergent, and processed cheese, both typical CPG categories but with market-specific penetration, purchase rate and branding. The results for these categories were similar to those of all other categories, all 35 of which clearly demonstrated clear DJ patterns. This is followed by an analysis of the market structure and buying behaviour of the BOP segment and a summary of model fittings across all categories.

\subsection{Laundry Detergents}

The metrics in Table 2 show familiar patterns of split-loyal buying for a frequently bought category that reaches almost every household. The main pattern in the table is that 
theoretical and observed purchase frequencies vary together $(r=.83 ; p=.003)$. A Wilcoxon signed-rank test showed no significant difference between observed and theoretical values $(Z=-1.224, p=.240)$. Market share, penetration, and SCR are all strongly correlated with purchase frequency and with each other (average $r=0.9$ ). The proportion buying any brand just once is larger for smaller brands, and bigger brands have higher repeat rates. In addition, the percentage buying a brand six or more times is lower for smaller brands, so that not only do small brands have fewer buyers, but those buyers also buy less often (a DJ pattern).

Table 2 about here

Note that one brand, Leader HS, is clearly out of line $(\%$ error $=130)$ with purchase frequency double the theoretical prediction $(\mathrm{T}=4.2 ; \mathrm{O}=9.7)$. This is because Leader HS is strongly promoted and distributed in rural areas where poorer consumers buy small pack sizes, frequently, raising the brand's purchase rate. This segmentation strategy is also why Leader $H S$ has only a third of the market share of brands with similar purchase frequency, showing that share depends more on the number of buyers than on buying frequency.

Typically, the customer base of a brand includes many one-time buyers, and few loyal buyers. Looking at the top 4 brands, more buyers buy $6+$ times, compared to once. Yet on average, only $1 \%$ are $100 \%$ loyal (i.e., $99 \%$ of category buyers are switchers) - loyalty is not exclusive.

Note that market metrics of liquid soap (LS) deviate from the general patterns. LS is purchased by A and B class consumers where 6 of the top 10 brands were liquid, while only 3 were bought by the middle classes, and none by class $E$. Industry practitioners 
explained that LS is an innovation in Egypt, and higher SECs are more capable of adopting it, e.g. by buying new washing machines that can use it.

The detergent category shows that established patterns of normal buying behaviour are present. Some slight deviations from theoretical values suggest market partitioning due to differences in distribution and product formats; these are also found in mature markets.

\subsection{Processed cheese}

Table 3 shows that BPMs for cheese brands also align closely to brand penetration. Purchase frequency varies less than penetration - the biggest brand has 14 times the penetration but only 3 times the purchase frequency of the smallest brand - a DJ pattern. This says that the number of brand buyers and not their degree of loyalty explain differences in brand size. In sum, DJ patterns are again dominant $(r=0.72 ; p=.018$; Wilcoxon $\mathrm{Z}=-0.178, \mathrm{p}=.883$ ), MAPE was acceptable at $21 \%$ and MAD at 0.6 points.

Table 3 about here

Elseedy has a higher than predicted purchase rate (42\% error). As a smaller brand with 9\% market share, Elseedy has relatively more frequent buyers $(6+$ times), high SCR (46\%) and high purchase frequency of $100 \%$ loyal consumers. Further analysis found that like Leader HS in detergents, Elseedy is popular with the SEC E where it has $24 \%$ market share and purchase frequency of 4.7. Few from SEC A or B buy it because its distribution and promotion is focused on poorer areas. This in turn raises the question of whether the particularities of BOP consumer segments may violate the known laws of marketing. We now proceed to a closer analysis of BOP markets to find out. 


\subsection{BOP Consumer Buying Patterns}

Of the Egyptian consumer market's six socio-economic classes, the largest is class E (31\%), which is also the poorest (BOP). The richest, Class A, is a tiny $0.4 \%$ of the population. In practice, most international marketers target class A because of its wealth and concentrated distribution. The marketplace outcomes of targeting strategies can be seen in Table 4 showing the top brands of laundry detergent for each SEC.

The market leader (Ariel HS) leads in 5 of 6 SECs; and the top four brands are the same in 4 of 6 SECs. The two where the leading brands are slightly different are A and B small, rich segments that together make up just $6 \%$ of the population. The brands targeting these segments tend to be small e.g., Persil LS and Ariel LS each have 2\% market share. In contrast, the five biggest brands are big with the poorer but bigger SECs, suggesting that marketers who seek size and growth should target as broadly as possible.

Table 4 about here

Table 5 shows that the BOP segment has all the normal buying behaviour of the category as a whole; looking down the columns, purchase frequency varies directly with size of the brands, the percentage of buyers buying each brand once, $2+, 4+$, etc. is similar to the figures for the overall market, and high purchase frequencies for the top brands suggests that bigger brands enjoy more repeat buying than smaller -- a classic DJ pattern.

Table 5 about here 
Table 5 also shows that all BPMs vary together. Again Leader $H S$ (variance $=130 \%$ ) is out of line--as it was to the overall category patterns because of its small pack sizes and increased buying rate (Prahalad, 2005; Simanis \& Hart, 2008). Even so, the DJ patterns remain clear. If Leader $H S$ is removed from the analysis, $M A P E$ drops to an acceptable $21 \%$. Thus observed deviations can be explained, in this case by the marketing strategies of certain brands, and not by any peculiarities of BOP consumers.

\subsection{Analysis of Egypt's CPG category competitive structure}

To verify the generalizability of the findings, analysis was extended to 35 categories, and over 800 brands. The observed results for every category were compared against theoretical values and confirmed that the DJ equation closely predicts buying rates $(r=$ $.99 ; p=.000)$, with acceptable error $(M A P E=15 \%$, Wilcoxon $Z=-.059, p=.992)$.

In established markets, CPG market leaders usually have slightly lower market shares than the $40 \%$ observed here (about $37 \%$, Euromonitor, 2016), and market share tends to be more evenly distributed between competitors. And while it might be expected in the BOP that the biggest brands would be the cheaper domestic ones, in fact, a third are foreign, showing that foreign brands can not only become established, but also attain leadership. Note also that the household category penetration of $70 \%$ suggests that most Egyptian households bought most categories at least once in fifteen months.

Next the implications for developing theoretical and practical knowledge are discussed. 


\title{
5.0 Discussion
}

\begin{abstract}
learning occurs when the findings obtained through replication studies are integrated with previous research to arrive at or update empirical generalizations. Bass \& Wind (1995) hold that "Science is a process in which data and theory interact leading to generalized explanations of disparate types of phenomena. Thus, empirical generalizations are the building blocks of science." This underlines the importance of research for establishing generalizability and boundary conditions in disparate settings. BOP research contexts are widely disparate to the 'traditional' context of highly developed markets. If established EGs hold in new contexts, they build confidence in the universality of a theory. If on the other hand, the results fail to hold, boundary conditions may be established. In either case, marketing science progresses.
\end{abstract}

This paper contributes to marketing theory first via a differentiated replication of the stochastic $w(1-b)$ modelling technique in a new context characterized by rapid growth, category immaturity, and masses of BOP consumers. The resulting empirical analyses show how stochastic modeling techniques represent a fruitful area for the development of explanatory theory.

The second contribution is to provide empirical evidence that patterns of behaviour typical of mature advanced economies are also generated in a very different BOP market. Against the view that "an entirely new strategic process" is required (Simanis \& Hart, 2008), this study provides guidance by showing that in cross section the assumptions underlying the Double Jeopardy law are not violated when analysing dynamic market data. This helps to advance knowledge and provides insight for international strategic marketing planning, by making it possible to predict consumer buying behaviour. This in 
turn provides guidelines for where to direct marketing efforts and robust benchmarks against which to evaluate results.

If DJ assumptions hold in BOP markets, then brand choice behaviour follows familiar rules; the biggest brands are those that can tackle the bigger demographic segments to acquire more buyers. For every brand, the majority of its customer base will be light buyers because they regularly buy other brands too. The key to brand size is therefore total buyer numbers, not buyer loyalty.

The third contribution is to demonstrate that the idea that market structures or buying behaviour at the BOP are markedly different is ripe for re-thinking and empirical testing (section 2.0 above, e.g., Luiz, 2006; Batra, 1999; Eyring et al, 2011). This study shows that BOP buyer behaviour has many familiar characteristics (Uncles et al, 2010; Bayne et al, 2014) and that understanding both the similarities and differences are vital to the formation of effective marketing strategy. BOP buying patterns are virtually identical to those seen in other markets. Nor are BOP consumers constrained to low price or generic products (as might have been expected), rather, they buy across the brand spectrum (Subrahmanyan \& Gomez-Ariaz, 2008), further supporting the premise that there are solid bottom-line reasons to develop BOP marketing strategies (Guesalaga \& Marshall, 2008; Agnihotri, 2013).

The fourth contribution concerns brand leaders that are often far larger than their nearest competitors. Whether they are local, regional, or multinational, what unites them is that they target the broader market, especially the BOP, exploiting their positional advantages (Martin, Javalgi \& Cavusgil, 2017) or market embeddedness (Halaszovich \& Lundan, 2016). The finding that both AMNEs and emerging multinational enterprises (EMNEs) 
can attain category leadership suggests that the BOP holds opportunity for sales and growth.

Empirical evidence in this study revealed buying behaviour that was consistent across all categories. Even with "expected" divisions, such as between AMNE brands and local imitators the BPMs differ only according to the size of the brand. This is because consumers see the products as functionally similar, as substitutes - even at very different price points. Similar patterns have been reported in many other markets; for Chinese retailers (Uncles et al, 2010; Uncles \& Kwok, 2008), South African banks (Bayne et al, 2014) and Nigerian and Kenyan soft drinks (Romaniuk \& Sharp, 2016).

\subsection{Marketer imposed restrictions}

Brands that restrict their marketing to certain small market segments (e.g., targeting SEC A) tend to remain small. Even if they are market leaders within the selected segments, they enjoy very little market share in the overall market. This is in line with Sharp (2010) and Romaniuk \& Sharp's (2016) arguments against brands that place restrictions on their growth by trying to "lock" and own buyers of a certain segment.

BOP purchasing is instead limited by the brands' marketing and distribution efforts. Some brands (Leader $H S$ detergent) focus on dispersed rural BOP buyers, and do exceptionally well with them, but not because BOP buyers have unusual loyalty patterns (or deviate from theoretical values). If managers choose to serve the BOP segment, the evidence shows that they can expect BOP consumers to respond in ways that follow the law-like patterns of consumer buying observed elsewhere.

The benefit of targeting all possible category buyers is that it enables brands to grow large. And with size, come higher loyalty metrics (a DJ pattern). While the practical 
difficulties of reaching millions of buyers may mean that managers only have the resources to address some segments, they are still better off targeting the BOP segment and the smallest SEC A. Targeting A alone will never deliver the same volume.

\subsection{Conclusions}

In established markets the route to growth is through salience - the brand must be both mentally and physically available at the buying situation to increase the chances of being bought. And when bought, brands are usually bought by light buyers who are a great majority in every market (Sharp, 2010; Romaniuk et al, 2018). DJ holds across the BOP in every category observed, and brands that achieve leadership are those that gain salience across the whole market - successfully increasing their chances for every sale. Also, leadership means success beyond that in developed economies since it tends to create a two-fold difference in share between leader and challenger. The evidence therefore suggests that there is ample scope for a fortune at the bottom of the pyramid, and it follows a well-established pattern.

\subsection{Research limitations \& suggestions for future research}

The collection of consumer panel data in BOP markets is quite new and this dataset is relatively small, which limits the generalizability of this research. As available data becomes more accurate, representative and reliable, it will enable comparisons between different slices of time, additional categories, and different markets, enabling analysis to move from the cross-sectional to the longitudinal.

The empirical results raise new questions about market structure. While there is room for growth at the BOP, how can brands secure market presence that will enable that growth? What strategies do category leading brands follow? How does the strategy vary for local, 
regional and multinational brands? Is targeting the whole market a viable alternative for resource-constrained companies? And if not, what are the better choices to leverage inmarket capabilities and resource bases? How does product or brand innovation fit in strategic marketing planning for BOP consumers? Attempts at tackling such questions will further contribute to the theoretical development of the international marketing literature.

This research demonstrates that consumer behavior EGs are found in the BOP segment. But this is not to say that all BOP segments are the same--one in India may be quite unlike one in Algeria, Bangladesh or even different states in India, and further research should investigate how BOP consumers behave especially in underexplored markets. Further, such studies could be replicated over time and across industries to identify how behaviors evolve over time as markets develop.

BOP deviations from DJ norms are also potential areas for theory development. The under-prediction of one-time buying observed in some categories and consequent overprediction of loyalty metrics present potentially valuable directions for research and model refinement. More research is required to determine whether these deviations are present in other markets, and whether the model could be modified to accommodate the particular conditions. These insights into market structure, and deviations from theoretical norms help to focus future research questions towards consolidating theory through in-depth and long-term research.

This article details the findings from an application of the Double Jeopardy Law. The discoveries are encouraging. The next steps will involve fitting more complex models, for example the NBD-Dirichlet (Goodhardt et al., 1984) that can estimate a wider range of metrics across competing brands, including duplication of purchase, share-based 
loyalty measures and other norms including brand Pareto share. 


\section{References}

Agnihotri, A. (2013) Doing good and doing business at the bottom of the pyramid, Business Horizons, V56(5) 591-599

Bang, V. Joshi, S. \& Singh, M. (2016) Marketing strategy in emerging markets: A conceptual framework, Journal of Strategic Marketing, 24(2) 104-107

Bass, F. \& Wind, J. (1995) Introduction to the Special Issue: Empirical Generalizations in Marketing, Marketing Science, G1-G5

Batra, R. (1999) Marketing Issues in Transitional Economies, New York: Kluwer Academic Publishers

Bayne, T. Samuels, B. \& Sharp, B. (2014) Marketing banks: target new, not loyal customers, Admap, April, 40-41

Bound, J. (2009) The S parameter in the Dirichlet-NBD model: A simple interpretation, Journal of Empirical Generalisations in Marketing Science, 12(3) 1-7

Brewis-Levie, M. \& Harris, P. (2000) An empirical analysis of buying behaviour in UK high street womenswear retailing using the Dirichlet model, The International Review of Retail, Distribution and Consumer Research, 10(1) 41-57

Brown, S. (1995) Life begins at 40? Further thoughts on marketing's 'mid-life crisis', Marketing Intelligence \& Planning, 13(1) 4-17

Brandt, L. \& Thun, E. (2010) The fight for the middle: Upgrading, competition, and industrial development in China, World Development 38(11) 1555-1574

Burgess, SM. \& Steenkamp, J. (2013) Editorial: Introduction to the Special Issue on Marketing in Emerging Markets, International Journal of Research in Marketing, 30, 1-3

Cateora, P. Gilly, M. Graham, J. \& Farah M. (2014) International Marketing, Middle East edition, McGraw Hill, NY

Chikweche, T. (2013) Revisiting the business environment at the bottom of the pyramid (BOP) - From theoretical considerations to practical realities, Journal of Global Marketing, 26, 239-257

Collins, D., Morduch, J., Rutherford, S. \& Ruthven, O. (2011) Portfolios of the Poor; How the World's Poor live on \$2 a Day, Princeton University Press, Princeton, NJ, 3

Coussy, J. (2009) Emerging countries: An attempt at typology. In C. Jaffrelot (Ed.), Emerging states: The wellspring of a new world order. New York, NY: Columbia University Press

D 'Andrea, G., Marcotte, D. \& Morrison, G. (2010) Let emerging market customers be your teachers, Harvard Business Review, December, 115-120 
Dawes, John (2016) Brand growth in packaged goods markets: Ten cases with common patterns. Journal of Consumer Behaviour 15 (5) 475-489

Doyle, J. Filo, K. McDonald, H. \& Funk, D. (2013) Exploring sport double brand jeopardy: The link between team market share and attitudinal loyalty, Sport Management Review, 16, 285-297

Easton, G. (2002) Marketing: a critical realist approach, Journal of Business Research, 55 (2) $103-109$

Ehrenberg, A. S. C. (1988) Repeat-Buying: Facts, theory and applications. 2nd ed. New York: Oxford University Press.

Ehrenberg, A. \& Goodhardt, G. (2001) New brands: Near-instant loyalty, Journal of Targeting, Measurement and Analysis for Marketing, 10(1) 9-16

Ehrenberg, A. Goodhardt, G. \& Barwise, P. (1990) Double jeopardy revisited, Journal of Marketing, 54 (July) 82-91

Ehrenberg, A. Uncles, M. \& Goodhardt, G. (2004) Understanding brand performance measures: using Dirichlet benchmarks, Journal of Business Research, 57, 1307-1325

Euromonitor, (2016) https://blog.euromonitor.com/2015/01/estimating-category-leadersin-fmcg-industries.html

Eyring, M. Johnson, M. \& Nair, H. (2011) New business models in emerging markets. Engineering Management Review, IEEE, 42(2) 19-26

Gapminder Org. Dollar Street project (2019), pyramidhttps://www.gapminder.org/dollarstreet/family?place $=54 \mathrm{~b} 7 \mathrm{e} 39 \mathrm{~d} 25003 \mathrm{a} 824 \mathrm{f} 648 \mathrm{a} 60$

Ghemawat, P. \& Altman, S. (2016) Emerging Economies: Differences and Distances, AIB Insights, 16(4) 1-9

Goodhardt, G. Ehrenberg, A \& Chatfield, C. (1984) The Dirichlet: A Comprehensive Model of Buying Behaviour, Journal of the Royal Statistical Society, 147 (part 5) 621-55

Graham, C. (2009) What's the point of Marketing anyway? The prevalence, temporal extent and implications of long-term market share equilibrium, Journal of Marketing Management, 25 (9-10) 867-874

Graham, C. Bennett, D. Franke, K. Lu-Henfrey, C. \& Nagy-Hamada, M. (2017) Double Jeopardy 50 years on. Reviving a forgotten too that still predicts brand loyalty, Australasian Marketing Journal, 25, 278-287

Gruneklee, N. Rundle-Thiele, S. \& Kubacki, K. (2016) What can social marketing learn from Dirichlet theory patterns in a physical activity context? Marketing Intelligence and Planning, 34(1) 41-60

Gueslaga, R \& Marshall, P. (2008) "Purchasing power at the bottom of the pyramid: differences across geographic regions and income tiers", Journal of Consumer Marketing, 25 (7) 413-418 
Hahn, R. (2009) The ethical rational for the poor: Integrating the concepts bottom of the pyramid, sustainable development, and corporate citizenship, Journal of Business Ethics, $84,313-324$

Halaszovich, T \& Lundan, S. (2016) The moderating role of local embeddedness on the performance of foreign and domestic firms in emerging markets, International Business Review, 25(5) 1136-1148

Hanssens, D.M.(2018) The value of empirical generalizations in marketing $J$. of the Acad. Mark. Sci. 46: 6. https://doi.org/10.1007/s11747-017-0567-0

Hanssens, D \& Pauwels, K. (2016) Demonstrating the value of marketing, Journal of Marketing, 80 (November) 173-790

Hillemann, J. \& Verbeke, A. (2014) An internationalization theory perspective on the bottom of the pyramid, International Business and Sustainable Development, 69-90

Hunt, S. (1994) On rethinking marketing: our discipline, our practice, our methods, European Journal of Marketing 28 (3) 13-25

Jagtap, S. Larsson, A. Hiort, V. Olander, E. Warell, A. \& Khadilkar, P. (2014) How design process for the base of the pyramid differs from that for the top of the pyramid, Design Studies, 35(5) 527-558

Karnani, A. (2007). Misfortune at the bottom of the pyramid. Greener Management Journal, 51, 99-110.

Kolk, A. Rivera-Santos, M \& Rufin, C. (2014) Reviewing a decade of research on the "Base/Bottom of the pyramid" (BOP) concept, Business and Society 53(3) 338-377

Kotler, P. \& Kotler, M. (2012) Market your way to growth, Wiley

Kucuk, S. (2010) Negative double jeopardy revisited: A longitudinal analysis, Journal of Brand Management, 18(2) 150-158

Kumar, V, Sarang, S \& Sharma A. (2015) Leveraging Distribution to Maximize Firm Performance in Emerging Markets, Journal of Retailing, 91(4) 627-643

Luiz, J. (2006) Managing Business in Africa. Cape Town: Oxford University Press

Malhotra, N. Baalbaki, I. \& Bechwati, N. (2010) Marketing Research (Arab World edition) Essex: Pearson

Martin, S. Javalgi. R, \& Cavusgil, E. (2017) Marketing capabilities positional advantage, and performance of born global firms: Contingent effects of ambidextrous innovation, International Business Review, 26(3) 527-543

Miller, R. (1998) Selling to Newly Emerging Markets, New York: Quorum Books

Nakata, C. \& Weidner, K. (2012) Enhancing new product adoption at the base of the pyramid: A contextualized model, Journal of Product Innovation Management, 29(1) 2132 
Oxford Business Group publications, (2017) Major policy developments and reforms in Egypt drive economic growth

Pleshko, L. \& Souiden, N. (2007) A preliminary study of double jeopardy in selected retailers, Academy of Marketing Studies Journal, 11(2) 87-105

Prahalad, C. (2005) The fortune at the bottom of the pyramid: Eradicating poverty through profits. New Delhi: Pearson Education and Wharton School.

Rangan, V. Chu, M. \& Petkoski, D. (2011) The globe: Segmenting the base of the pyramid, Harvard Business Review, June. Available from https://hbr.org/2011/06/theglobe-segmenting-the-base-of-the-pyramid

Romaniuk, J. \& Sharp, B (2016), How brands grow Part 2, Oxford University Press

Romaniuk, J. (2013) Modeling mental market share, Journal of Business Research, 66, $188-195$

Romaniuk, J, Dawes, J \& Nenycz-Thiel M. (2018)"Modeling brand market share change in emerging markets", International Marketing Review, 35(5), 785-805

Sharp, B. Wright, M, Kennedy, R \& Nguyen, C (2017) Viva la revolution! For evidencebased marketing we strive, Australasian Marketing Journal 25(4) 252-260

Sharp, B. (2010) How brands grow: What marketers don't know. South Melbourne: Oxford University Press

Sharp, B. Wright, M. Dawes, J. Driesner, C. Meyer-Waarden, L. Stocchi, L. \& Stern, P. (2012) It's a Dirichlet world: Modeling individuals' loyalties reveals how brands compete, grow and decline, Journal of Advertising Research, 52(2) 203-213

Sheth, J. (2011) Impact of emerging markets on marketing: Rethinking existing perspectives and practices, Journal of Marketing, 75(4) 166-182

Simanis, E. (2012) Reality check at the base of the pyramid, Harvard Business Review, June

Simanis, E. \& Hart, S. (2008) The Base of the Pyramid Protocol: Toward Next Generation BoP Strategy ( $2^{\text {nd }}$ ed.), Center for Sustainable Enterprise, Cornell University

Singh, J. Goodhardt, G. \& Ehrenberg, A. (2004) Loyalty to Product Variants - A Pilot, Journal of Customer Behaviour, 3(2) 123-132

Subrahmanyan, S \& Gomez-Ariaz, T. (2008) Integrated approach to understanding consumer behavior at bottom of pyramid, Journal of Consumer Marketing, 25(7) $402-412$

Trinh, G. T. and Anesbury, Z. W. (2015) An Investigation of Variation in Brand Growth and Decline across Categories, International Journal of Market Research, 57(3) 347356.

UN publications (2014), UNIDO activities in Egypt, United Nations Industrial Development Organization. Retrieved from 
https://www.unido.org/sites/default/files/201405/UNIDO 2014 Report Egypt updated 0.pdf

Uncles, M., Wang, C. \& Simon, K. (2010) A temporal analysis of behavioural brand loyalty among urban Chinese consumers, Journal of Marketing, 26(9-10) 921-942

Uncles, M. \& Kwok, S. (2008) Generalizing patterns of store-type patronage: an analysis across major Chinese cities, International Review of Retail, Distribution and Consumer Research, 18(5) 473-493

Uncles, M. \& Wright, M. (2004) Empirical generalisation in marketing, Australasian Marketing Journal, Editorial, 12(3) 5-18

Viswanathan, M. \& Sridharan, S. (2012) Product development for the BoP: Insights on concept and prototype development from university-based student projects in India, Journal of Product Innovation Management, 29(1) 52-69

Weissburg, J. (2008) The BOP beckons: Why grassroots design will determine the winners in developing markets, Stanford Social Innovation Review, Spring, 21-22

World Resources Institute (2018) The Next 4 Billion, Market Size and Business Strategy at the Base of the Pyramid, access online at:https://www.wri.org/search/site/BOP?f $\% 5 \mathrm{~B} 0 \% 5 \mathrm{D}=$ bundle $\% 3$ Apublication

Wright, M. \& Riebe, E. (2010) Double jeopardy in brand defection, European Journal of Marketing, 44(6) 860-873

WTO (2018) World Trade Organization: Members and observers. Retrieved from https://www.wto.org/english/thewto e/whatis e/tif e/org6 e.htm 
Figure 1. The Ehegwo family has an income of about $\$ 59$ per month

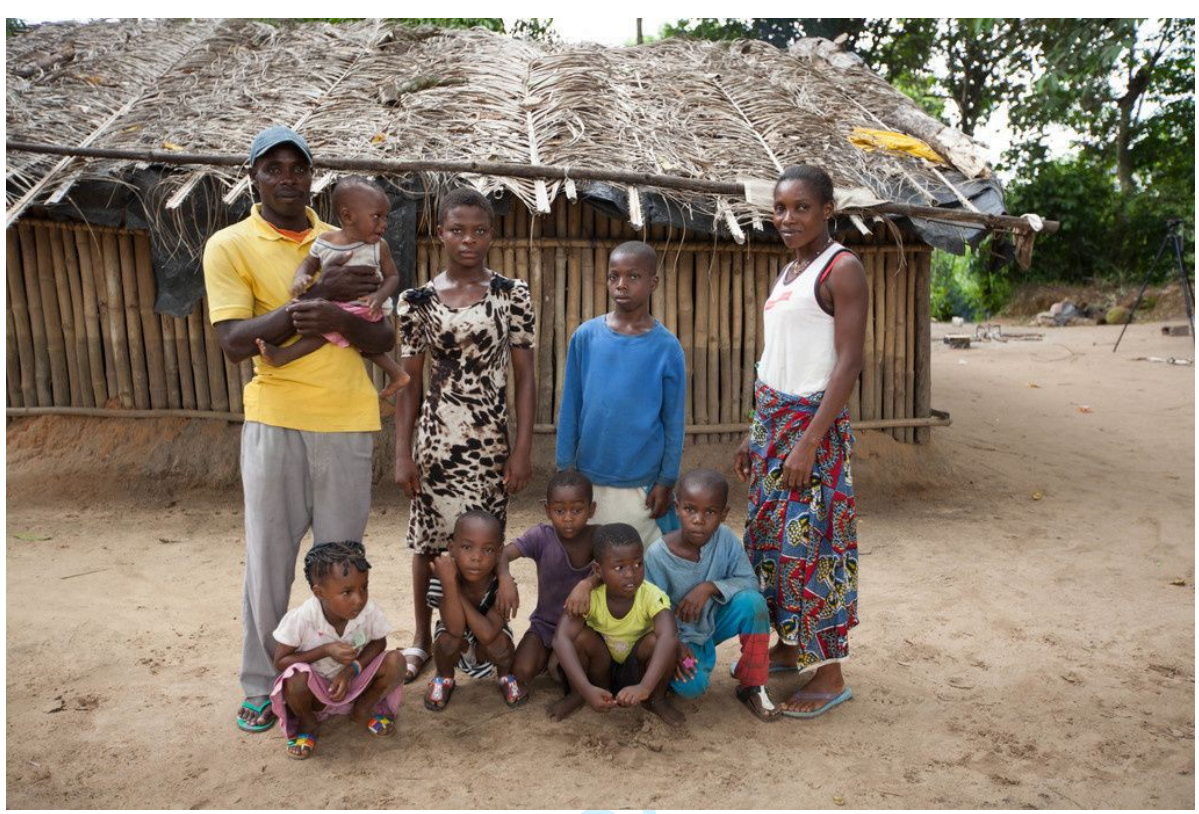

Figure 2. The Ehegwo's kitchen

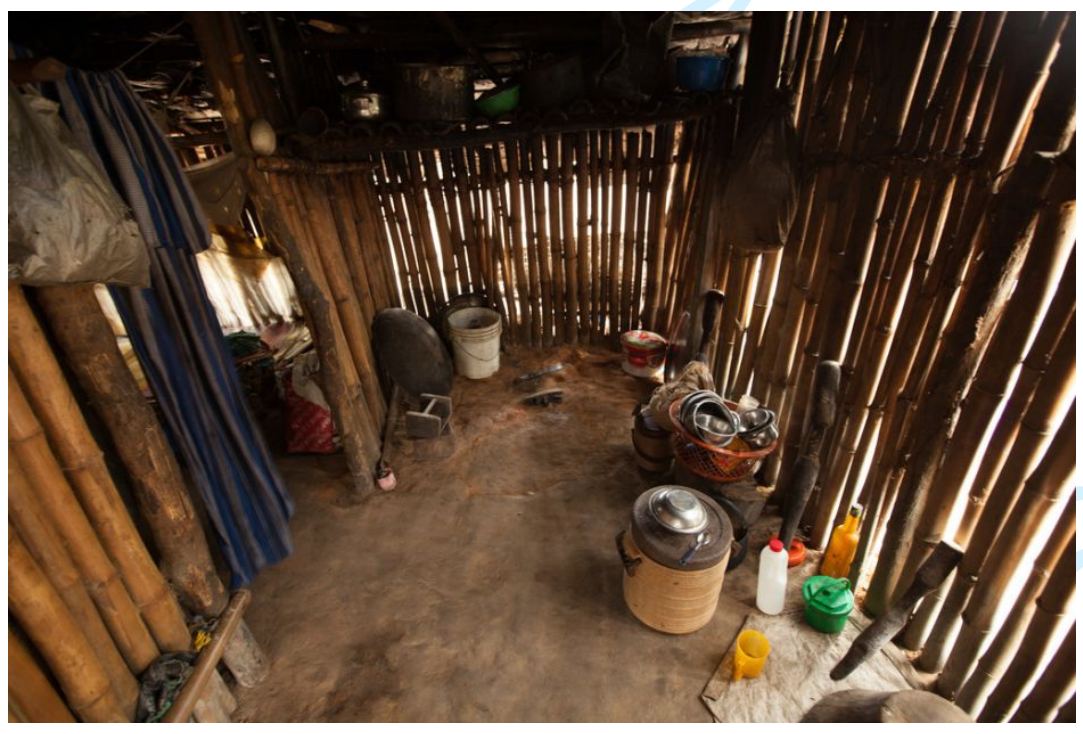

Figure 3. Branded consumer goods, toothpaste

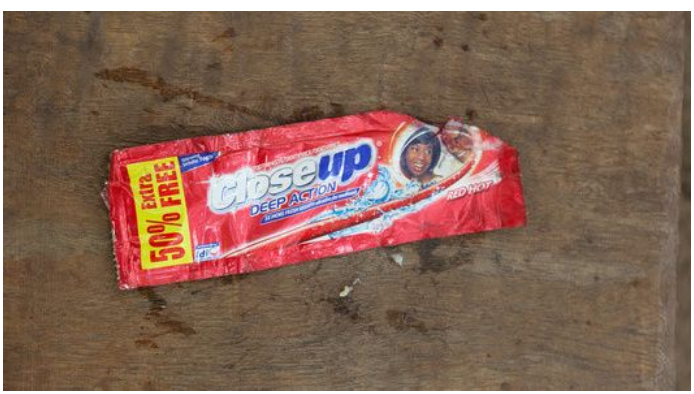


Table 1. Top 10 BOP markets, millions of adults

\begin{tabular}{|lcc|}
\hline \multicolumn{1}{|c|}{ adults $18+$ (millions) } & $\%$ under poverty line \\
India & 379 million & $22 \%$ \\
China & 239 & 4 \\
Indonesia & 57 & 11 \\
Nigeria & 44 & 70 \\
Brazil & 32 & 4 \\
Ethiopia & 31 & 30 \\
Pakistan & 30 & 30 \\
DR Congo & 30 & 63 \\
Egypt & 30 & 28 \\
Philippines & 29 & 22 \\
\hline
\end{tabular}

Source column 1 Euromonitor's income and wealth model, 2015; Column 2 CIA World Factbook, 2019

Figure 4: The skewed distribution of Socio-economic classes (SECs) in Egypt

\begin{tabular}{llcc}
\hline $\begin{array}{l}\text { SOCIO- } \\
\text { ECONOMIC } \\
\text { CLASS (SEC) }\end{array}$ & TITLE & $\begin{array}{l}\text { PERCENT } \\
(\%)\end{array}$ & $\begin{array}{l}\text { HOUSEHOLD MONTHLY } \\
\text { INCOME BRACKET } \\
\text { (EGYPTIAN POUNDS) }\end{array}$ \\
\hline A & Higher upper class & 0.4 & $20,000+$ \\
B & Upper class & 5 & $12,000-19,999$ \\
C1 & Upper middle class & 11 & $6,000-11,999$ \\
C2 & Lower middle class & 26 & $1,500-5,999$ \\
D & Lower class & 27 & $500-1,499$ \\
E & Very low class (BOP) & 31 & Up to 499 \\
\hline
\end{tabular}

These socio-economic classes (SECs) were defined to establish international comparability. In addition to household income, occupation, education, club membership, travel, owned durables, transportation and residence were considered. 
Table 2. Brand Performance Metrics for Laundry Detergents, Egypt 2015-2016

\begin{tabular}{|c|c|c|c|c|c|c|c|c|c|c|c|c|}
\hline \multirow{2}{*}{$\begin{array}{l}\text { Detergent } \\
\text { Top } 10 \\
\text { (96\% of } \\
\text { sales) }\end{array}$} & \multirow{2}{*}{$\begin{array}{c}\text { Market } \\
\text { Share } \\
\% \\
\end{array}$} & \multirow{2}{*}{$\begin{array}{c}\text { Penetration } \\
\% \\
b \\
\end{array}$} & \multicolumn{2}{|c|}{$\begin{array}{c}\text { Average Purchase } \\
\text { Frequency }\end{array}$} & \multicolumn{4}{|c|}{ \% Buying } & \multicolumn{2}{|c|}{ Category } & \multicolumn{2}{|c|}{$100 \%$ Loyal } \\
\hline & & & $\begin{array}{c}\text { Observed } \\
w\end{array}$ & $\begin{array}{c}\text { Theoretical } \\
w_{d} /(1-b)\end{array}$ & Once & $2+$ & $4+$ & $6+$ & Purchase & $\operatorname{SCR}(\%)$ & $\begin{array}{c}\text { Pen. } \\
\%\end{array}$ & $\begin{array}{l}\text { Avg } \\
\text { Purch }\end{array}$ \\
\hline Category & 100 & 94 & 29.2 & & & & & & & & & \\
\hline Ariel HS & 36 & 80 & 12.5 & 16.8 & 9 & 14 & 12 & 64 & 30 & 41 & 2 & 10.3 \\
\hline Persil HS & 26 & 75 & 9.4 & 13.3 & 18 & 20 & 14 & 49 & 31 & 30 & 2 & 16.4 \\
\hline Oxi HS & 15 & 59 & 7.1 & 8.1 & 25 & 26 & 13 & 37 & 33 & 22 & 1 & 15.2 \\
\hline Leader HS & 8 & 22 & 9.7 & 4.2 & 22 & 21 & 13 & 44 & 35 & 28 & 3 & 23.0 \\
\hline Extra HS & 3 & 17 & 4.7 & 4.0 & 38 & 26 & 13 & 23 & 32 & 15 & 0 & 35.5 \\
\hline Ariel LS & 2 & 20 & 3.2 & 4.1 & 39 & 31 & 11 & 18 & 25 & 13 & 1 & 6.4 \\
\hline Tide HS & 2 & 19 & 2.9 & 4.1 & 52 & 27 & 8 & 12 & 33 & 9 & 0 & 1.0 \\
\hline Persil LS & 2 & 14 & 3.4 & 3.8 & 44 & 24 & 10 & 21 & 24 & 14 & 1 & 3.4 \\
\hline Tide LS & 1 & 12 & 3.0 & 3.7 & 48 & 25 & 12 & 14 & 24 & 13 & 1 & 3.6 \\
\hline Loose HS & 1 & 9 & 4.2 & 3.6 & 55 & 19 & 6 & 20 & 35 & 12 & 1 & 1.0 \\
\hline Average & 10 & 33 & 6.0 & 6.6 & 35 & 23 & 11 & 30 & 30 & 20 & 1 & 11.6 \\
\hline \multicolumn{13}{|l|}{$\underline{O} v s \mathbf{T}$} \\
\hline Correlation & & & & 0.83 & & & & & & & & \\
\hline MAD & & & & 1.9 & & & & & & & & \\
\hline MAPE \% & & & & 32 & & & & & & & & \\
\hline
\end{tabular}

Data Source: Kantar WorldPanel

The observed loyalty in the entire category is lower than expected with the exception of Leader HS which is strongly niching 
Table 3- Brand Performance Metrics for Processed Cheese, Egypt 2015-2016

\begin{tabular}{|c|c|c|c|c|c|c|c|c|c|c|c|c|}
\hline \multirow{2}{*}{$\begin{array}{l}\text { Cheese } \\
\text { Top 10 } \\
97 \% \text { of } \\
\text { sales } \\
\end{array}$} & \multirow{2}{*}{$\begin{array}{c}\text { Market } \\
\text { Share } \\
\%\end{array}$} & \multirow{2}{*}{$\begin{array}{c}\text { Penetration } \\
\% \\
b \\
\end{array}$} & \multicolumn{2}{|c|}{ Purchase frequency } & \multicolumn{4}{|c|}{ \% Buying } & \multicolumn{2}{|c|}{ Category } & \multicolumn{2}{|c|}{$100 \%$ Loyal } \\
\hline & & & $\begin{array}{c}\text { Observed } \\
w \\
\end{array}$ & $\begin{array}{c}\text { Theoretical } \\
w_{o} /(1-b)\end{array}$ & Once & $2+$ & $4+$ & $6+$ & Purchase & $\operatorname{SCR}(\%)$ & $\begin{array}{c}\text { Pen. } \\
\%\end{array}$ & $\begin{array}{l}\text { Avg } \\
\text { Purch }\end{array}$ \\
\hline Category & 100 & 70 & 7.2 & & & & & & & & & \\
\hline President & 35 & 41 & 4.4 & 3.9 & 34 & 29 & 14 & 22 & 9 & 51 & 24 & 3.8 \\
\hline Teama & 17 & 29 & 2.9 & 3.3 & 48 & 29 & 10 & 13 & 9 & 33 & 16 & 2.8 \\
\hline Other & 10 & 18 & 2.8 & 2.8 & 53 & 28 & 8 & 11 & 9 & 32 & 20 & 1.9 \\
\hline La Vache & 10 & 14 & 3.5 & 2.7 & 46 & 25 & 10 & 18 & 12 & 30 & 7 & 1.9 \\
\hline Milkana & 9 & 14 & 3.2 & 2.7 & 44 & 31 & 11 & 14 & 10 & 33 & 17 & 3.5 \\
\hline Elseedy & 9 & 12 & 3.7 & 2.6 & 39 & 30 & 14 & 18 & 8 & 46 & 21 & 5.1 \\
\hline Kiri & 4 & 10 & 2.3 & 2.5 & 60 & 29 & 4 & 8 & 12 & 19 & 6 & 1.3 \\
\hline Firo & 1 & 3 & 2.1 & 2.4 & 60 & 24 & 9 & 7 & 7 & 32 & 18 & 2.7 \\
\hline Labanita & 1 & 3 & 1.5 & 2.4 & 72 & 25 & 1 & 2 & 14 & 11 & 6 & 1.0 \\
\hline Domty & 1 & 3 & 1.4 & 2.4 & 71 & 27 & 2 & 0 & 14 & 10 & 7 & 1.0 \\
\hline Average & 10 & 15 & 2.8 & 2.8 & 53 & 28 & 8 & 11 & 10 & 30 & 14 & 2.5 \\
\hline \multicolumn{13}{|l|}{$\underline{O}$ vs $\mathbf{T}$} \\
\hline Correlation & & & & 0.72 & & & & & & & & \\
\hline MAD & & & & 0.6 & & & & & & & & \\
\hline MAPE \% & & & & 21 & & & & & & & & \\
\hline
\end{tabular}


Table 4. Top 5 brands (in rank share order) in each of the 6 SECs in the laundry detergent category

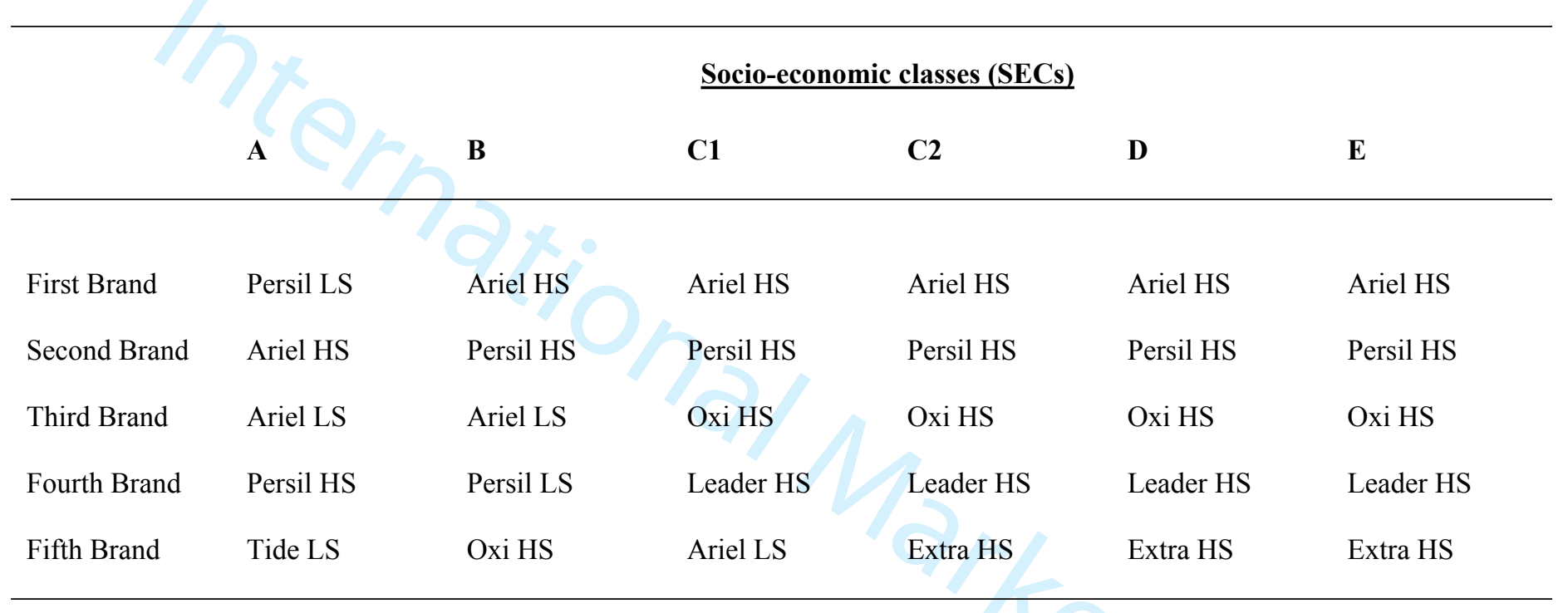

A Wilcoxon signed-rank test showed no significant difference between observed and theoretical values $(Z=-1.020, p=.336)$.

Ariel is the leading brand in the entire category, and in all SECs except for A.

These few richest category buyers do not choose the local \& regional brands 
Table 5. Brand Performance Metrics in SEC E, showing DJ patterns at the BOP. Egypt 2015-2016

\begin{tabular}{|c|c|c|c|c|c|c|c|c|c|c|c|c|}
\hline \multirow{2}{*}{$\begin{array}{l}\text { Detergents } \\
\text { Top } 10 \\
99 \% \text { of sales }\end{array}$} & \multirow{2}{*}{$\begin{array}{c}\text { Market } \\
\text { Share }\end{array}$} & \multirow{2}{*}{$\frac{\text { Penetration }}{\%}$} & \multicolumn{2}{|c|}{ Purchase freq } & \multirow[b]{2}{*}{ Once } & \multicolumn{2}{|c|}{ \% buying } & & \multicolumn{2}{|c|}{$\underline{\text { Category }}$} & \multicolumn{2}{|c|}{$\underline{100 \% \text { loyal }}$} \\
\hline & & & $\begin{array}{c}\text { Observed } \\
w\end{array}$ & $\begin{array}{c}\text { Theoretical } \\
w_{d} /(1-b)\end{array}$ & & $2+$ & $4+$ & $6+$ & Purchs & SCR & Pen & $\begin{array}{c}\text { Av } \\
\text { purch }\end{array}$ \\
\hline Category & & 98 & 35.1 & & & & & & & & & \\
\hline Ariel HS & 32 & 79 & 13.8 & 17.1 & 10 & 13 & 12 & 65 & 36 & 39 & 1 & 11.4 \\
\hline Persil HS & 26 & 79 & 11.5 & 17.1 & 14 & 14 & 12 & 60 & 37 & 31 & 2 & 25.8 \\
\hline Oxi HS & 17 & 68 & 8.6 & 11.3 & 17 & 23 & 14 & 46 & 37 & 23 & 2 & 23.3 \\
\hline Leader HS & 13 & 36 & 12.9 & 5.6 & 13 & 18 & 12 & 57 & 37 & 35 & 5 & 25.7 \\
\hline Extra HS & 4 & 26 & 5.4 & 4.9 & 37 & 21 & 14 & 28 & 35 & 16 & 1 & 3.0 \\
\hline Tide HS & 2 & 22 & 3.6 & 4.6 & 51 & 25 & 7 & 16 & 38 & 9 & 0 & 0.0 \\
\hline Bonux HS & 2 & 14 & 3.7 & 4.2 & 45 & 24 & 13 & 18 & 42 & 9 & 0 & 0.0 \\
\hline loose HS & 1 & 9 & 4.2 & 4.0 & 53 & 18 & 3 & 26 & 35 & 12 & 2 & 1.0 \\
\hline Bahy HS & 1 & 7 & 4.5 & 3.9 & 43 & 36 & 4 & 17 & 43 & 11 & 0 & 0.0 \\
\hline Other & 1 & 13 & 2.2 & 4.1 & 62 & 23 & 9 & 6 & 40 & 5 & 0 & 0.0 \\
\hline Average & & 35 & 7.0 & 7.7 & 35 & 22 & 10 & 34 & 38 & 19 & 1 & 9.0 \\
\hline $\begin{array}{l}\text { O vs T } \\
\text { Correlation } \\
\text { MAD }\end{array}$ & & & & $\begin{array}{c}0.78 \\
2.4\end{array}$ & & & & & & & & \\
\hline MAPE \% & & & & 32 & & & & & & & & \\
\hline
\end{tabular}

Data Source: Kantar WorldPanel 


\section{Appendix 1}

\begin{tabular}{|c|c|c|}
\hline Citation & Full citation & Research sample \\
\hline $\begin{array}{l}\text { Allenby \& Lenk } \\
\text { (1994) }\end{array}$ & $\begin{array}{l}\text { Allenby, GM. \& Lenk, PJ. (1994) Modelling household purchase behavior with logistic normal regression, } \\
\text { Journal of the American Statistical Association, 89(428), pp.1218-1231 }\end{array}$ & US \\
\hline $\begin{array}{l}\text { Bandyopadhyay \& } \\
\text { Gupta (2004) }\end{array}$ & $\begin{array}{l}\text { Bandyopadhyay, S., Gupta, K. (2004), Comparing double jeopardy effects at the behavioral and attitudinal } \\
\text { levels, Journal of Product \& Brand Management, 13(3), pp.180 - } 191\end{array}$ & North America \\
\hline $\begin{array}{l}\text { Barwise \& } \\
\text { Ehrenberg (1985) }\end{array}$ & $\begin{array}{l}\text { Barwise, PT., Ehrenberg, ASC, (1985) Consumer beliefs and brand usage, Journal of Market Research } \\
\text { Society,27, pp.81-93 }\end{array}$ & UK \\
\hline Bayne et al (2014) & $\begin{array}{l}\text { Bayne, T., Samuels, B. \& Sharp, B. (2014) Marketing banks: target new, not loyal customers, Admap, April, } \\
\text { pp.40-1 }\end{array}$ & South Africa \\
\hline $\begin{array}{l}\text { Bennett \& Graham } \\
(2010)\end{array}$ & $\begin{array}{l}\text { Bennett, D. \& Graham, C. (2010) Is loyalty driving growth for the brand in front? A two-purchase analysis of } \\
\text { car category dynamics in Thailand, Journal of Strategic Marketing, 18(7), pp.573-585 }\end{array}$ & Thailand \\
\hline Bennett (2008) & $\begin{array}{l}\text { Bennett, D. (2008) Brand Loyalty Dynamics - China's Television brands come of age, Australasian } \\
\text { Marketing Journal } 16 \text { (2), pp. 39-50 }\end{array}$ & China \\
\hline $\begin{array}{l}\text { Bowman \& Lele- } \\
\text { Pingle (1997) }\end{array}$ & $\begin{array}{l}\text { Bowman, D., \& Lele-Pingle, S. (1997), Buyer behavior in business-to-business services: The case of foreign } \\
\text { exchange, International Journal of Research in Marketing, 14(5), pp.499-508 }\end{array}$ & North America \& Europe \\
\hline $\begin{array}{l}\text { Brewis-Levie \& } \\
\text { Harris (2000) }\end{array}$ & $\begin{array}{l}\text { Brewis-Levie, M. \& Harris, P. (2000) An empirical analysis of buying behaviour in UK high street } \\
\text { womenswear retailing using the Dirichlet model, The International Review of Retail, Distribution and } \\
\text { Consumer Research, 10(1), 41-57, }\end{array}$ & UK \\
\hline $\begin{array}{l}\text { Brewis-Levie and } \\
\text { Harris (2000) }\end{array}$ & $\begin{array}{l}\text { Brewis-Levie, M., \& Harris, P. (2000) An empirical analysis of buying behaviour in UK high street } \\
\text { womenswear retailing using the Dirichlet model. The International Review of Retail, Distribution and } \\
\text { Consumer Research, 10(1), pp.41-57 }\end{array}$ & UK \\
\hline $\begin{array}{l}\text { Colombo, Ehrenberg, } \\
\& \text { Sabavala (2000) }\end{array}$ & $\begin{array}{l}\text { Colombo, R., Ehrenberg, A., \& Sabavala, D. (2000) Diversity in analyzing brand-switching tables: The car } \\
\text { challenge. Canadian Journal of Marketing Research, 19, pp.23-36 }\end{array}$ & Europe \\
\hline Danaher et al. (2003) & $\begin{array}{l}\text { Danaher, PJ., Wilson, IW., \& Davis, RA. (2003) A comparison of online and offline } \\
\text { consumer brand loyalty. Marketing Science, 22(4), pp.461-476 }\end{array}$ & US \\
\hline Dawes (2002) & $\begin{array}{l}\text { Dawes, J. G. (2002) Survey responses using scale categories follow a "Double Jeopardy" } \\
\text { pattern. Australian and New Zealand Marketing Academy Conference, Melbourne }\end{array}$ & Australia \\
\hline
\end{tabular}




\begin{tabular}{|c|c|c|}
\hline Doyle et al (2013) & $\begin{array}{l}\text { Doyle, JP., Filo, K., McDonald, H., Funk, DC. (2013), Exploring sport double brand jeopardy: The link } \\
\text { between team market share and attitudinal loyalty, Sport Management Review, 16, pp.285-297 }\end{array}$ & Australia \\
\hline $\begin{array}{l}\text { Ehrenberg \& } \\
\text { Goodhardt (2001) }\end{array}$ & $\begin{array}{l}\text { Ehrenberg, A. \& Goodhardt, GJ. (2001) New brands: Near-instant loyalty, Journal of Targeting, Measurement } \\
\text { and Analysis for Marketing, 10(1), p.9-16 }\end{array}$ & UK \\
\hline $\begin{array}{l}\text { Ehrenberg et al } \\
\text { (2004) }\end{array}$ & $\begin{array}{l}\text { Ehrenberg, AS., Uncles, M. \& Goodhardt, G. (2004), Understanding brand performance measures: using } \\
\text { Dirichlet benchmarks, Journal of Business Research, 57, p.1307-1325 }\end{array}$ & US, UK, Germany \& Japan \\
\hline $\begin{array}{l}\text { Ehrenberg, et al. } \\
\text { (1990) }\end{array}$ & $\begin{array}{l}\text { Ehrenberg, ASC., Goodhart, GJ. \& Barwise, TP. (1990), Double Jeopardy revisited, Journal of Marketing, 54, } \\
\text { pp.82-91 }\end{array}$ & US \& UK \\
\hline Graham (2009) & $\begin{array}{l}\text { Graham, CA. (2009) What's the point of Marketing anyway? The prevalence, temporal extent and } \\
\text { implications of long-term market share equilibrium, Journal of Marketing Management, } 25(9-10) \text {, pp.867-874 }\end{array}$ & UK \\
\hline $\begin{array}{l}\text { Greenacre et al } \\
(2015)\end{array}$ & $\begin{array}{l}\text { Greenacre, L., Tanusondjaja, A., Dunn, S., Page, B. (2015) Using choice experiments to find double jeopardy } \\
\text { patterns, International Journal of Market Research, 57(5), pp.743-758 }\end{array}$ & US \\
\hline $\begin{array}{l}\text { Gruneklee et. Al } \\
(2016)\end{array}$ & $\begin{array}{l}\text { Gruneklee, N., Rundle-Thiele, S., Kubacki, K., (2016), What can social marketing learn from Dirichlet theory } \\
\text { patterns in a physical activity context? Marketing Intelligence and Planning, 34(1), p.41-60 }\end{array}$ & Australia \\
\hline $\begin{array}{l}\text { Kalwani, Meyer \& } \\
\text { Morrison (1994) }\end{array}$ & $\begin{array}{l}\text { Kalwani, MU., Meyer, RJ., \& Morrison, DG. (1994) Benchmarks for discrete choice models, Journal of } \\
\text { Marketing Research, 31, pp. 65-75 }\end{array}$ & US \\
\hline Kau et al (1998) & $\begin{array}{l}\text { Kau, KA., Uncles, MD., Ehrenberg, ASC., Barnard NR., (1998) Competitive brand choice and store-choice } \\
\text { among Japanese consumers, Journal of Product Brand Management, 7(6), pp.481-94 }\end{array}$ & Japan \\
\hline $\begin{array}{l}\text { Keng, Uncles, } \\
\text { Ehrenberg \& Barnard } \\
\text { (1998) }\end{array}$ & $\begin{array}{l}\text { Keng, K. A., Uncles, M., Ehrenberg, A., \& Barnard, N. (1998). Competitive brand-choice and store-choice } \\
\text { among Japanese consumers. The Journal of Product and Brand Management, 7, pp. 481-494 }\end{array}$ & Japan \\
\hline $\begin{array}{l}\text { Labeaga-Azcona et } \\
\text { al (2010) }\end{array}$ & $\begin{array}{l}\text { Labeaga-Azcona, JM., Lado-Cousté, N., Martos-Partal, M. (2010) The double jeopardy loyalty effect } \\
\text { using discrete choice models, International Journal of Market Research, 52(5), pp.633-652 }\end{array}$ & Spain \\
\hline $\begin{array}{l}\text { McDonald, Sharp, \& } \\
\text { Ehrenberg (2002) }\end{array}$ & McDonald, C., Sharp, B., \& Ehrenberg, A. S. C. (2002) Impulse purchasing patterns. & UK \\
\hline $\begin{array}{l}\text { Meyer-Waarden \& } \\
\text { Benavent (2006) }\end{array}$ & $\begin{array}{l}\text { Meyer-Waarden, L., \& Benavent, C. (2006) The impact of loyalty programs on repeat purchase behavior, } \\
\text { Journal of Marketing Management, 22(1/2), pp.61-88 }\end{array}$ & France \\
\hline $\begin{array}{l}\text { Pare \& Dawes } \\
(2012)\end{array}$ & $\begin{array}{l}\text { Pare,V. \& Dawes, J. (2012) The persistence of excess brand loyalty over multiple years, Marketing Letters, } \\
\text { 23, pp.163-175 }\end{array}$ & UK \\
\hline
\end{tabular}




\begin{tabular}{|c|c|c|}
\hline $\begin{array}{l}\text { Pickford \& } \\
\text { Goodhardt (2000) }\end{array}$ & $\begin{array}{l}\text { Pickford, C., \& Goodhardt, G. (2000) An empirical study of buying behaviour in an industrial market, } \\
\text { AM2000, Academy of Marketing Annual Conference, University of Derby, Derby CD Proceedings }\end{array}$ & UK \\
\hline $\begin{array}{l}\text { Pleshko \& Souiden } \\
(2007)\end{array}$ & $\begin{array}{l}\text { Pleshko, LP. \& Souiden, NS. (2007) A preliminary study of Double Jeopardy in selected retailers, Academy } \\
\text { of Marketing Studies Journal, 11(2), pp.87-105 }\end{array}$ & US \\
\hline Riebe et al (2014) & $\begin{array}{l}\text { Riebe, E., Wright, M., Stern, P., Sharp, B. (2014) How to grow a brand: Retain or acquire customers?, Journal } \\
\text { of Business Research, 67, pp.990-997 }\end{array}$ & UK \\
\hline $\begin{array}{l}\text { Romaniuk \& Sharp } \\
\text { (2016) }\end{array}$ & Romaniuk, J. \& Sharp, B (2016), How brands grow Part 2, Oxford University Press & Indonesia, Nigeria \& Kenya \\
\hline $\begin{array}{l}\text { Scriven \& Ehrenberg } \\
\text { (1994) }\end{array}$ & Scriven, J., \& Ehrenberg, ASC. (1994) The structure of the UK petrol market. & UK \\
\hline $\begin{array}{l}\text { Sharp \& Driesener } \\
(2000)\end{array}$ & $\begin{array}{l}\text { Sharp, B., Driesener, C.(2000) The Dirichlet's Buyer Behaviour Assumptions Really Do Matter, ANZMAC } \\
2000 \text { Visionary Marketing for the } 21 \text { st Century: Facing the Challenge, pp. 1144-1148 }\end{array}$ & Australia \\
\hline Sharp (2010) & Sharp, B. (2010) How brands grow: What marketers don't know. South Melbourne: Oxford University Press & $\begin{array}{l}\text { UK, US, Australia, France, } \\
\text { South Africa }\end{array}$ \\
\hline $\begin{array}{l}\text { Sharp \& Sharp } \\
(1997)\end{array}$ & $\begin{array}{l}\text { Sharp, B., \& Sharp, A. (1997), Loyalty programs and their impact on repeat-purchase loyalty patterns, } \\
\text { International Journal of Research in Marketing, 14(5), pp. 473-486 }\end{array}$ & Australia \\
\hline Sharp et al (2012) & $\begin{array}{l}\text { Sharp, B., Wright, M., Dawes, J., Driesner, C., Meyer-Waarden, L., Stocchi, L., Stern, P. (2012), It's a } \\
\text { Dirichlet world: Modelling individuals' loyalties reveals how brands compete, grow and decline, Journal of } \\
\text { Advertising Research, 52(2), p.203-213 }\end{array}$ & US \& UK \\
\hline $\begin{array}{l}\text { Sharp, Wright, and } \\
\text { Goodhardt (2002) }\end{array}$ & $\begin{array}{l}\text { Sharp, B., Wright, M., \& Goodhardt, G. (2002) Purchase loyalty is polarised into either repertoire or } \\
\text { subscription patterns, Australasian Marketing Journal, 10(3), pp.7 }\end{array}$ & Australia \& New Zealand \\
\hline $\begin{array}{l}\text { Singh, Ehrenberg, \& } \\
\text { Goodhardt (2004) }\end{array}$ & $\begin{array}{l}\text { Singh, J., Ehrenberg, A., \& Goodhardt, G. (2008) Measuring customer loyalty to product variants, } \\
\text { International Journal of Market Research, 50(4), pp.513-532 }\end{array}$ & US \& UK \\
\hline $\begin{array}{l}\text { Stern \& Ehrenberg } \\
(1995)\end{array}$ & $\begin{array}{l}\text { Stern, P., \& Ehrenberg, ASC. (1995) The marketing performance of pharmaceutical brands, Marketing and } \\
\text { Research Today, 23(4), pp. 285-290 }\end{array}$ & UK \\
\hline $\begin{array}{l}\text { Uncles \& Kwok } \\
(2008)\end{array}$ & $\begin{array}{l}\text { Uncles, MD \& Kwok, S. (2008) Generalizing patterns of store-type patronage: an analysis across major } \\
\text { Chinese cities, International Review of Retail, Distribution and Consumer Research, 18(5), p.473-493 }\end{array}$ & China \\
\hline $\begin{array}{l}\text { Uncles \& Kwok } \\
(2009)\end{array}$ & $\begin{array}{l}\text { Uncles, MD, \& Kwok, S. (2009) Patterns of store patronage in urban China, Journal of Business Research, } \\
62(1) \text {, pp. } 68-81\end{array}$ & China \\
\hline
\end{tabular}




\begin{tabular}{|l|l|l|}
$\begin{array}{l}\text { Uncles \& Hammond } \\
(1995)\end{array}$ & $\begin{array}{l}\text { Uncles, M., \& Hammond, K. (1995) Grocery store patronage, The International Review of Retail, Distribution } \\
\text { and Consumer Research, 5(3), pp. 287-302 }\end{array}$ & UK \\
\hline Uncles et al (2010) & $\begin{array}{l}\text { Uncles, M., Wang, C. \& Simon, K. (2010), A temporal analysis of behavioural brand loyalty among urban } \\
\text { Chinese consumers, Journal of Marketing, 26(9-10), p.921-942 }\end{array}$ & China \\
\hline $\begin{array}{l}\text { Wright \& Riebe } \\
(2010)\end{array}$ & $\begin{array}{l}\text { Wright, M \& Riebe, E. (2010), Double jeopardy in brand defection, European Journal of Marketing, } \\
\text { 44(6), pp. 860 - 873 }\end{array}$ & UK \& Australia \\
\hline $\begin{array}{l}\text { Wright \& Sharp } \\
(1999)\end{array}$ & $\begin{array}{l}\text { Wright, M., \& Sharp, A. (1999) New brand effects in a Dirichlet market, 28th European Marketing Academy } \\
\text { Conference, Berlin, Germany, CD Proceedings }\end{array}$ & Australia \\
\hline Wright et al (1998) & $\begin{array}{l}\text { Wright, M., Sharp, A. \& Sharp, B. (1998) Are Australasian brands different? Journal of Product Brand } \\
\text { Management, 7(6), pp.465 - 80 }\end{array}$ & Australia \\
\hline $\begin{array}{l}\text { Wright, Sharp, \& } \\
\text { Sharp (2002) }\end{array}$ & $\begin{array}{l}\text { Wright, M., Sharp, A., \& Sharp, B. (2002). Market statistics for the Dirichlet model: Using the Juster scale to } \\
\text { replace panel data, International Journal of Research in Marketing, 19(1), pp.81-90 }\end{array}$ & Australia \\
\hline
\end{tabular}

